\title{
A model for evaluating beef cattle rations considering effects of ruminal fiber mass
}

\section{Douglas Sampaio Henrique ${ }^{1^{*}}$, Rogério de Paula Lana ${ }^{2}$, Ricardo Augusto Mendonça Vieira ${ }^{3}$, Carlos Augusto de Alencar Fontes ${ }^{3}$, Mosar Faria Botelho ${ }^{4}$}

\footnotetext{
1 Programa de Pós-graduação em Zootecnia UFV, Viçosa, MG

2 Universidade Federal de Viçosa.

3 Universidade Estadual do Norte Fluminense Darcy Ribeiro.

${ }^{4}$ Universidade Tecnológica Federal do Paraná.
}

\begin{abstract}
A mathematical model based on Cornell Net Carbohydrate and Protein System (CNCPS) was developed and adapted in order to evaluate beef cattle rations at tropical climate conditions. The presented system differs from CNCPS in the modeling of insoluble particles' digestion and passage kinetics, which enabled the estimation of fiber mass in rumen and its effects on animal performance. The equations used to estimate metabolizable protein and net energy requirements for gain, net energy requirement for maintenance and total efficiency of metabolizable energy utilization were obtained from scientific articles published in Brazil. The parameters of the regression equations in these papers were estimated using data from Bos indicus purebred and crossbred animals reared under tropical conditions. The model was evaluated by using a 368-piece of information database originally published on 11 Doctoral theses, 14 Master's dissertations and four scientific articles. Outputs of the model can be considered adequate.
\end{abstract}

Key Words: modeling, nutrition, ruminants

\section{Introduction}

The nutritional management is of great importance for the beef cattle production due its large impact on the production costs and animal performance. Several computational tools have been developed aiming to reduce feeding costs. In 1961, Waugh applied linear programming techniques to solve the problem of feeding costs minimization for dairy cows (Agrawal \& Heady, 1972). The continuous increase in scientific information and complexity concerning the established relationships between animal, food and environment, has led to the inevitable incorporation of non-linear functions in the recently developed models (NRC, 1996; NRC, 2001; Fox et al., 2004).

The system developed at Cornell University - CNCPS (Cornell Net Carbohydrate and Protein System) is a mathematical model to evaluate diets and performance of dairy and beef cattle, and it has been used and improved since its publication in 1992 (Fox et al., 2004). The referred system can be considered as a great innovation in the ways of determining the transformations of the ingested nutrients in the rumen. Its set of equations has helped to better quantify the degradation and escape processes of different carbohydrates and nitrogen fractions in the rumen, and allowed to estimate microbial growth more accurately than its predecessors (Fox et al., 1992).

Henceforth, a model based on CNCPS set of equations for beef cattle diets was adapted and evaluated by considering degradation and transit kinetic properties of feedstuffs to estimate protein and energy adequacy of diets in relation to animal requirements. The improvements were done to enhance average daily gain prediction for feedlot cattle under tropical conditions.

\section{Material and Methods}

The set of mathematical expressions that constitute CNCPS (Russell et al., 1992; Sniffen et al., 1992; Tedeschi et al., 2000; Fox et al., 2004), were modified to some extent (Tables 1 and 2) to account for a generalized approach related to feed passage and degradation kinetics in the ruminant gastrointestinal tract (Vieira et al., 2008ab). The energy and protein requirements were predicted according to parameters estimated under tropical feedlot conditions (Fontes, 1995; Henrique et al., 2005), with the exception of the maintenance protein requirement (Fox et al., 1992). The complete set of mathematical expressions related to the presented approach can be found in Henrique (2007). 
Instead of the five CNCPS fractions, the feed crude protein was divided into four fractions, namely: A, representing the non-protein fraction in short peptides; B1 or neutral detergent soluble true protein, grouped as such due to its nutritional uniformity (Van Soest, 1967; Broderick, 1994; Rodrigues \& Vieira, 2006); B2 or potentially degradable neutral detergent insoluble true protein; and $\mathrm{C}$ or indigestible true protein.

The fractions that compose the feed total carbohydrates (TC) are: A', or low molecular weight carbohydrates (simple sugars) soluble in neutral detergent solution; B1', in which there are non-fibrous compounds of polymeric nature (soluble in neutral detergent), such as non-amylaceous polysaccharides and starch (Van Soest et al., 1991; Hall, 2003); B2', or potentially degradable fibrous carbohydrates insoluble in neutral detergent solution; and C', which is basically indigestible fibrous carbohydrates encrusted by lignin (Sniffen et al., 1992).
The present model was evaluated with information obtained from 11 Doctoral theses and 14 Master's dissertations developed at the Universidade Federal de Viçosa (Barbosa, 1978; Margon, 1981; Galvão, 1991; Estrada, 1996; Gesualdi Júnior, 1999; Resende, 1999; Backes, 2003; Magalhães, 2003; Miranda, 2005; and Obeid, 2005), Universidade Estadual Paulista (Arrigoni, 1995; Henrique, 2002; Leão, 2002; Mendes, 2003; and Faturi, 2005), Universidade de São Paulo (Pereira, 2002; Putrino, 2002; Aferri, 2003; and Oliveira, 2004), Universidade Federal de Lavras (Fontes, 1993), Universidade Federal de Minas Gerais (Languidey, 1975; and Pacola, 1977) and Escola Superior de Agricultura Luiz de Queiroz (Bulle, 2000; Fernandes, 2004; and Almeida, 2005), and also four articles published at the Revista Brasileira de Zootecnia (Fernandes et al., 2004; Chizzotti et al., 2005; Silva et al., 2005; Pereira et al., 2006). From those data, 275 were related to individual observations obtained at the appendix of the theses and dissertations,

Table 1 - Definitions of symbols and acronyms used in the equations

\begin{tabular}{|c|c|c|}
\hline Symbol & Unit & Definition \\
\hline$C A_{i}^{\prime}$ & $\mathrm{g} \mathrm{d}^{-1}$ & Amount of sugars and organic acids ingested \\
\hline$C B 1_{i}^{\prime}$ & $\mathrm{g} \mathrm{d}^{-1}$ & Amount of fast degradable polysaccharides ingested \\
\hline$C B 2_{i}^{\prime}$ & $\mathrm{g} \mathrm{d}^{-1}$ & Amount of degradable fiber ingested \\
\hline$d E B M / d t$ & $\mathrm{~kg} \mathrm{~d}^{-1}$ & Empty body mass gain \\
\hline$d M / d t$ & $\operatorname{kg~d} \mathrm{d}^{-1}$ & Body mass gain \\
\hline$E B M$ & $\mathrm{~kg}$ & Empty body mass \\
\hline fiber $_{i}$ & $\mathrm{~g} \mathrm{~d}^{-1}$ & Amount of fiber ingested \\
\hline$F H C_{\max }$ & $\mathrm{g} \mathrm{kg}^{-1} \mathrm{M}$ & Fiber holding capacity of the rumen \\
\hline$k_{d 1 i}$ & $\mathrm{~h}^{-1}$ & Fraction B1 (soluble true protein) degradation rate \\
\hline$k_{d 1 i}{ }^{\prime} i$ & $h^{-1}$ & Fraction A' (sugars and organic acids) degradation rate \\
\hline$k_{d 2 i}$ & $\mathrm{~h}^{-1}$ & Fraction B2 (degradable protein insoluble in neutral detergent) degradation rate \\
\hline$k_{d 2}{ }_{i}^{\prime}$ & $h^{-1}$ & Fraction B1' (fast degradable polysaccharides) degradation rate \\
\hline$k_{d 2} i$ & $\mathrm{~h}^{-1}$ & Fraction B2’ (potentially degradable fiber) degradation rate \\
\hline$k_{e i}$ & $h^{-1}$ & Rate of ruminal escape of the fluid dispersed fibrous particles \\
\hline$k l$ & $h^{-1}$ & Liquid dilution rate in the rumen \\
\hline$k_{m g}$ & dmls & Gross efficiency of metabolizable energy use for maintenance and gain \\
\hline$k_{r i}$ & $h^{-1}$ & Passage rate of the long particle fiber to the ventral rumen portions \\
\hline $\ln$ & dmls & Natural logarithm \\
\hline$M$ & $\mathrm{~kg}$ & Body mass \\
\hline$M E I$ & MJ d $\mathrm{d}^{-1}$ & Metabolizable energy intake \\
\hline$M P_{g}$ & $\mathrm{~g} \mathrm{~d}^{-1}$ & Metabolizable protein required for gain \\
\hline$M R T_{i}$ & h & Mean retention time of fiber in the rumen \\
\hline$N$ & dmls & Positive integer order of time dependency related to the preparation of fiber to digestion \\
\hline$N E_{q}$ & $\mathrm{MJ} \mathrm{d}^{-1}$ & Net energy required for gain \\
\hline$N E_{m}^{y}$ & $\mathrm{MJ} \mathrm{d}^{-1}$ & Net energy requirement for maintenance \\
\hline$N E_{t}$ & $\mathrm{MJ} \mathrm{d}^{-1}$ & Total net energy ingested \\
\hline$N P_{g}$ & $\mathrm{~g} \mathrm{~d}^{-1}$ & Net protein requirement for gain \\
\hline$P B 1_{i}$ & $\mathrm{~g} \mathrm{~d}^{-1}$ & Amount of fraction B1 (soluble true protein) ingested \\
\hline$P B 2_{i}$ & $\mathrm{~g} \mathrm{~d}^{-1}$ & Amount of fraction B2 (degradable protein insoluble in neutral detergent) ingested \\
\hline$R D A_{i}^{\prime}$ & $\mathrm{g} \mathrm{d}^{-1}$ & Ruminally degraded sugars and organic acids \\
\hline$R D B 1_{i}$ & $\mathrm{~g} \mathrm{~d}^{-1}$ & Ruminally degraded soluble true protein \\
\hline$R D B 2_{i}^{i}$ & $\mathrm{~g} \mathrm{~d}^{-1}$ & Ruminally degraded protein insoluble in neutral detergent \\
\hline$R D B 1_{i}^{\prime}$ & $g \mathrm{~d}^{-1}$ & Ruminally degraded fast degradable polysaccharides \\
\hline$R D B 2^{\prime}{ }_{i}$ & $\mathrm{~g} \mathrm{~d}^{-1}$ & Ruminally degraded fiber \\
\hline$R E$ & Mcal d $\mathrm{d}^{-1}$ & Retained energy \\
\hline RFM & $\mathrm{g} \mathrm{kg}^{-1} \mathrm{M}$ & Ruminal fiber mass \\
\hline$U_{i}$ & dmls & Filling effect of the fiber in the rumen \\
\hline$x_{i}$ & $\mathrm{~g} \mathrm{~d}^{-1}$ & Dry matter intake \\
\hline$\beta_{g}$ & dmls & Efficiency of metabolizable protein utilization according to body size classes \\
\hline
\end{tabular}

*subscript "i" stands for ith feed. 
Table 2 - Equations used in the model that differ from CNCPS (version 5.0)

\begin{tabular}{|c|c|c|}
\hline Variable & Constraint & Equation \\
\hline$R D B 1_{i}$ & & $P B 1_{i} \cdot \frac{k_{d 1 i}}{k_{d 1 i}+\frac{1}{M R T_{i}}}$ \\
\hline$R D B 2_{i}$ & & $\frac{P B 2_{i} \cdot k_{d 2 i}}{k_{d 2 i}+k_{r i} / 3} \cdot\left(1+\frac{k_{r i} / 3}{k_{d 2 i}+k_{e i}}\right)$ \\
\hline$M R T$ & when $\mathrm{k}_{\mathrm{ri}}$ does not apply to ingredient $i$ & $\frac{1}{k_{e i}}$ \\
\hline & otherwise & $\frac{N}{k_{r i}}+\frac{1}{k_{e i}}$ \\
\hline$R D A^{\prime}{ }_{i}$ & & $C A_{i}^{\prime} \cdot \frac{k_{d 1}^{\prime} i}{k_{d 1 i}^{\prime}+k_{1}}$ \\
\hline$R D B 1^{\prime}{ }_{i}$ & & $C B 1_{i}^{\prime} \cdot \frac{k_{d 2}^{\prime}{ }^{\prime}}{k_{d 2}{ }^{\prime}{ }^{\prime}+\frac{1}{M R T_{i}}}$ \\
\hline$R D B 2_{i}{ }_{i}$ & & $C B 2_{i}^{\prime} \cdot \frac{k_{d 3^{\prime} i}}{k_{d 3_{i}}{ }^{\prime}+k_{r i} / 3} \cdot\left(1+\frac{k_{r i} / 3}{k_{d 3^{\prime}}{ }^{\prime}+k_{e i}}\right)$ \\
\hline$K l$ & & $k 1=3 \cdot \frac{\sum_{i=1}^{m} x_{i}}{\sum_{i=1}^{m} x_{i} \cdot M R T_{i}}$ \\
\hline $\mathrm{k}^{\mathrm{mg}}$ & & $\frac{0.305}{M E I \div M^{3 / 4}}-\frac{0.176}{M E I \div M^{3 / 4}}+0.37$ \\
\hline$E B M$ & $\begin{array}{c}\text { zebu } \\
\text { crossbred }\end{array}$ & $\begin{array}{l}-19.61+0.92 \cdot M \\
-34.34+0.92 \cdot M\end{array}$ \\
\hline$\frac{d E B M}{d t}$ & & $0.92 \cdot \frac{d M}{d t}$ \\
\hline$N P_{g}$ & zebu & $0.453 \cdot E B M_{Z}^{-0.184} \cdot 1000 \cdot \frac{d E B M}{d t}$ \\
\hline & crossbred & $0.631 \cdot E B M_{C}{ }^{-0.236} \cdot 1000 \cdot \frac{d E B M}{d t}$ \\
\hline $\mathrm{MP}_{\mathrm{g}}$ & & $\frac{\mathrm{N} N P_{g}}{\beta_{g}}$ \\
\hline$N E_{m}$ & & $0.305 \cdot E B M^{3 / 4}$ \\
\hline$N E_{g}$ & $\begin{array}{c}\text { zebu } \\
\text { crossbred }\end{array}$ & $\begin{array}{l}0.158 \cdot E B M^{0.568} \cdot 4.184 \cdot \frac{d E B M}{d t} \\
0.216 \cdot E B M^{0.479} \cdot 4.184 \cdot \frac{d E B M}{d t}\end{array}$ \\
\hline $\mathrm{U}_{\mathrm{i}}$ & & $\left.B 2^{\prime} \cdot \frac{k_{d 3 i^{\prime}}+k_{e i}+k_{r i} / N}{\left(k_{d 3}{ }^{\prime}+k_{r i} / N\right) \cdot\left(k_{d 3}{ }^{\prime}+k_{e i}\right)}+C^{\prime} \cdot\left(\frac{N}{k_{r i}}+\frac{1}{k_{e i}}\right)\right] \cdot 0.001$ \\
\hline RFM & & {$\left[\sum_{i=1}^{m}\left(\right.\right.$ fiber $\left.\left._{i} \cdot U_{i}\right)\right] \div M$} \\
\hline$F H C_{\max }$ & & {$\left[23.84-10.26 \cdot \ln \left(\frac{\sum_{i=1}^{m} f i b r_{i} \div M}{10}\right)\right]$} \\
\hline
\end{tabular}

and 93 were related to treatment averages, which totaled 368 data described in table 3. Animals’ characteristics were: average body mass in the studied period, genetic group, rate of body gain and total dry matter intake. Data concerning feed were: dietary components and chemical composition, when available. Necessary information for the calculation of protein and carbohydrate fractions used in the mathematical model was not completely described in all studies. These gaps were filled with the utilization of information contained in tables of feed composition for beef cattle, published by NRC (1996), Fox et al. (1999) and Valadares Filho et al. (2006).
The model evaluation was done by comparing graphically the values of net energy and metabolizable protein supplied by diets to those required by animals. Another evaluation was based on the comparison of the observed average individual body weight gain with those predicted by the model simulation, as follows:

$$
\begin{aligned}
& N E_{m}=\frac{0.305 \cdot M C V^{3 / 4}}{4.184} \\
& R E=\frac{N E_{t}}{4.184}-N E_{m} \\
& \frac{d M}{d t}=\frac{12.341 \cdot R E^{0.9116} \cdot E B M^{0.6837}}{0.956}(\mathrm{NRC}, 1996)
\end{aligned}
$$


Table 3 - Description of the evaluation set of data

\begin{tabular}{|c|c|c|c|c|c|c|}
\hline Genetic group & $\mathrm{n}$ & Gender & $\begin{array}{l}\mathrm{M}^{1} \\
(\mathrm{~kg})\end{array}$ & $\begin{array}{l}\mathrm{dM} / \mathrm{dt}^{2} \\
\left(\mathrm{~kg} \mathrm{~d} \mathrm{~d}^{-1}\right)\end{array}$ & $\begin{array}{l}\mathrm{DMI}^{3} \\
\left(\mathrm{~g} \mathrm{~d}^{-1}\right)\end{array}$ & Reference \\
\hline 3/4 European-Zebu & 3 & Steer & 394 & 1.16 & 8937 & Aferri (2003) \\
\hline $1 / 2$ Angus-Nellore & 1 & Bull & 427 & 1.566 & 9741 & Almeida (2005) \\
\hline $1 / 2$ Canchim-Nellore & 1 & Bull & 408 & 1.368 & 9086 & Almeida (2005) \\
\hline $1 / 2$ Simental-Nellore & 1 & Bull & 434 & 1.491 & 9622 & Almeida (2005) \\
\hline Nellore & 3 & Bull & 365 & 1.021 & 7651 & Almeida (2005) \\
\hline Nellore-Simental & 3 & Bull & 265 & 0.899 & 4950 & Arrigoni (1995) \\
\hline 1/2 Holstein-Zebu & 16 & Steer & 337 & 1.126 & 8268 & Backes (2003) \\
\hline Nellore & 8 & Steer & 321 & 1.106 & 7536 & Backes (2003) \\
\hline 5/8 Holstein-Zebu & 3 & Steer & 379 & 0.96 & 9365 & Barbosa (1978) \\
\hline 3/4 European-Zebu & 3 & Bull & 346 & 1.267 & 7307 & Bulle (2000) \\
\hline Nellore & 4 & Steer & 410 & 0.968 & 8425 & Chizzotti et al. (2005) \\
\hline 1/2 Nellore-Angus & 1 & Bull & 525 & 1.43 & 10660 & Estrada (1996) \\
\hline Nellore & 1 & Bull & 463 & 1.15 & 8800 & Estrada (1996) \\
\hline $1 / 2$ Nellore-Holstein & 1 & Bull & 527 & 1.41 & 10650 & Estrada (1996) \\
\hline $1 / 2$ Nellore-Normando & 1 & Bull & 532 & 1.55 & 10750 & Estrada (1996) \\
\hline $1 / 2$ Nellore-Angus & 4 & Steer & 407 & 1.284 & 10117 & Faturi (2005) \\
\hline Nellore e Canchim & 5 & Bull & 347 & 1.286 & 9333 & Fernandes (2004) \\
\hline 1/2 Caracu-Zebu & 2 & Bull & 337 & 0.926 & 7545 & Fernandes et al. (2004) \\
\hline 1/2 Holstein-Zebu & 2 & Bull & 339 & 1.103 & 7660 & Fernandes et al. (2004) \\
\hline Nellore & 2 & Bull & 333 & 1.122 & 7210 & Fernandes et al. (2004) \\
\hline Holstein-Zebu & 4 & Bull & 224 & 0.983 & 6375 & Fontes (1993) \\
\hline $1 / 2$ Nellore-Limousine & 12 & Bull & 427 & 1.238 & 9667 & Galvão (1991) \\
\hline $1 / 2$ Nellore-Marchigiana & 12 & Bull & 417 & 1.218 & 10268 & Galvão (1991) \\
\hline Nellore & 12 & Bull & 348 & 0.864 & 7970 & Galvão (1991) \\
\hline Santa Gertrudes & 4 & Bull & 379 & 1.53 & 8000 & Henrique (2002) \\
\hline $1 / 2$ Nellore-Limousine & 40 & Bull & 406 & 1.065 & 7781 & Gesualdi Júnior (1999) \\
\hline Holstein-Zebu & 5 & Bull & 315 & 0.65 & 7004 & Languidey (1975) \\
\hline Guzera & 75 & unavailable & 472 & 1.019 & 8749 & Leão (2002) \\
\hline Holstein-Zebu & 8 & Steer & 314 & 1.238 & 8571 & Magalhães (2003) \\
\hline Zebu & 32 & Steer & 384 & 0.462 & 7596 & Margon (1981) \\
\hline 3/4 Simental-Nellore & 3 & unavailable & 420 & 1.15 & 10543 & Mendes (2003) \\
\hline Caracu & 16 & Bull & 473 & 0.799 & 6654 & Miranda (2005) \\
\hline Nellore & 28 & Bull & 415 & 0.901 & 5817 & Miranda (2005) \\
\hline Zebu & 4 & unavailable & 440 & 1.363 & 9218 & Obeid (2005) \\
\hline Nellore & 3 & Steer & 431 & 1.141 & 10180 & Oliveira (2004) \\
\hline Zebu & 2 & unavailable & 336 & 1.109 & 10422 & Pacola (1977) \\
\hline Nellore & 3 & Steer & 350 & 1.46 & 7923 & Pereira (2002) \\
\hline Holstein-Zebu & 4 & Steer & 478 & 1.4 & 10925 & Pereira et al. (2006) \\
\hline 5/8 Angus-Nellore & 4 & Bull & 320 & 1.132 & 5793 & Putrino (2002) \\
\hline Nellore & 4 & Bull & 254 & 0.905 & 3378 & Putrino (2002) \\
\hline 5/8 Europeu-Zebu & 24 & Steer & 367 & 1.068 & 10095 & Resende (1999) \\
\hline Holstein-Zebu & 4 & Steer & 389 & 0.583 & 7348 & Silva et al. (2005) \\
\hline
\end{tabular}

${ }^{1}$ Body mass, ${ }^{2}$ Daily body gain; ${ }^{3}$ Dry matter intake.

Values of body weight gain observed and predicted were compared graphically and analyzed by means of their standardized residuals as suggested by Draper \& Smith (1966) and Montgomery (2005).

\section{Results and Discussion}

The total net energy $\left(N E_{t}\right)$ and metabolizable protein $(M P)$ supplied by the rations were 15\% (Figure 1 a) and 6\% (Figure 1a) higher than the animals' requirements for these nutrients, respectively. The nutrient supply and the animals' requirements are outputs calculated from the following inputs: observed dry matter intake, nutritional composition of the diets and daily body mass gain. Because of that, if the conclusion of the output analysis was that the amount of nutrients was not enough to meet the requirements, then the model would be considered improper. Nevertheless, the results were suitable for the performance of the animals and, consequently, the model was considered adequate for diet evaluations.

The model was also tested upon its capacity to predict performance of the animals from the observed dry matter intake and the nutritional composition of the diet. This evaluation was done by comparing the rate of body mass gain $(\mathrm{dM} / \mathrm{dt})$ predicted by the model with the observed values and analyzing their standard deviations. As it can be observed in Figure 1c, the average of predicted values was very close to the observed values, despite their great dispersion. The dispersion of the standard residuals as a 
function of average daily gain (Figure 1d) was randomly distributed around the zero axis, but presented a tendency to decline from 0.0 to $1.0 \mathrm{~kg}$ daily gain. These results are indicative that the model can be used to predict body mass gain when dry matter intake and ration composition are known, although some adjustments are still needed due to the great dispersion of residuals (Figure 1d). Even with high dispersion, $95 \%$ of the standard residuals are settled between -2 and 2.

Van Soest (1994) discusses about the energetic efficiency decrease (measured as a ratio between total net energy and total digestible nutrients contained in ration) as a function of the raise of fiber concentration of diet. According to the author, this effect was originally noticed by Kellner in 1912 and, since then, several hypotheses have been raised to explain it; among them, the raise in acetic acid proportion in rumen as a ratio of the raise of forage levels in diet and the higher heat production (calorific increment) generated rumination and fermentation of fibrous feed in the processes of mastication. Blaxter (1969) accomplished several studies where the effects of change of proportions of volatile fat acids (AGV) on energetic efficiency were quantified. Acetic acid proportions varying from $30 \%$ to $90 \%$ reduced the energetic efficiency for maintenance from $87 \%$ to $85 \%$ (Blaxter, 1969). Although the author did not analyze statistically the meaning of these differences, one can notice that the difference in the efficiency (around two percentage points) is low. Based on these results, Blaxter concluded that the efficiency with which the alimentary energy is utilized for maintenance is not greatly affected by the ruminal proportions of AGV. The same does not occur with energetic efficiency for body fat accumulation in adult animals (observed at intake levels superior than maintenance). In this case, efficiency was reduced from $58 \%$ to $32 \%$ when the acetic acid proportion increased from $50 \%$ to $68 \%$ (Blaxter, 1969). Concerning protein and fat accumulation in growing animals, Blaxter (1989), cited by Johnson et al. (2003), reported energetic efficiency of 30\% when fibrous
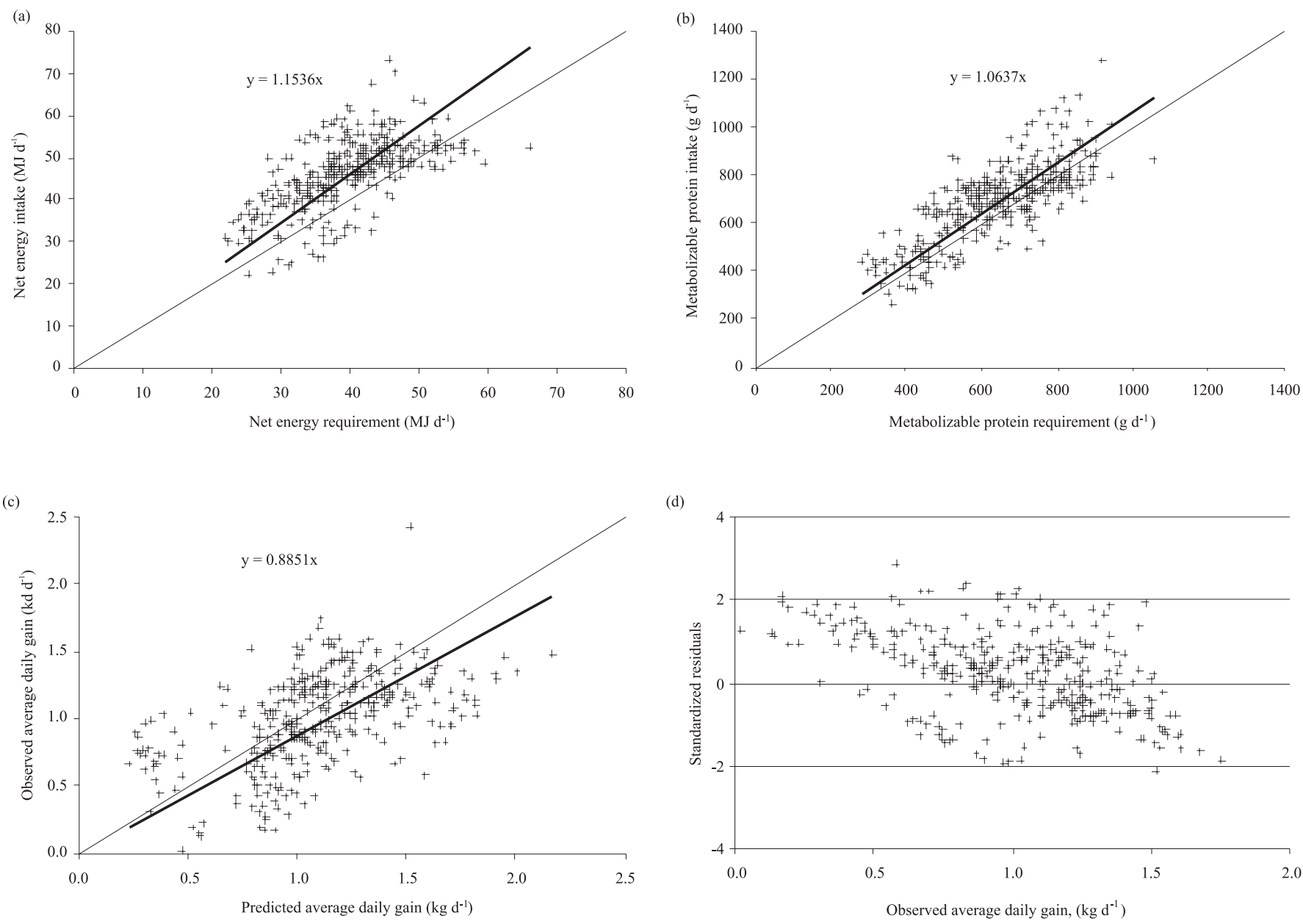

Figure 1 - Net energy (a) and metabolizable protein (b) supplied plotted against their respective requirement; observed versus predicted body mass gain rate (c) and average daily gain standardized residuals plotted against observed daily gain (d). 
feeds were used and attributed the low efficiency to the high calorific increment (measure of the energetic inefficiency) generated by the metabolic use of acetic acid as energy source. Despite these evidences, more efficient uses of acetic acid for animal growth were reported in several other experiments (Johnson, 1972; Orskov et al., 1979, cited by Johnson et al., 2003) and the mechanism responsible for high calorific increment of fibrous feed utilization for growth and fat accumulation continues to be unknowable (Van Soest, 1994; Johnson et al., 2003).

Energetic efficiency, measured with the same units used by Van Soest (1994), i.e., the ratio between total net energy and total apparently digestible nutrients contained in ration multiplied by 100 , did not suffer significant influence of fiber concentration in the diet $(\mathrm{r}=-0.04$ and $p$-value $=0.40$ ) when this analysis was done using the results obtained with the proposed model in this research. Therefore, the outputs of the presented model cannot be used to corroborate the theory that fiber concentration alone would influence the energetic efficiency.

(a)

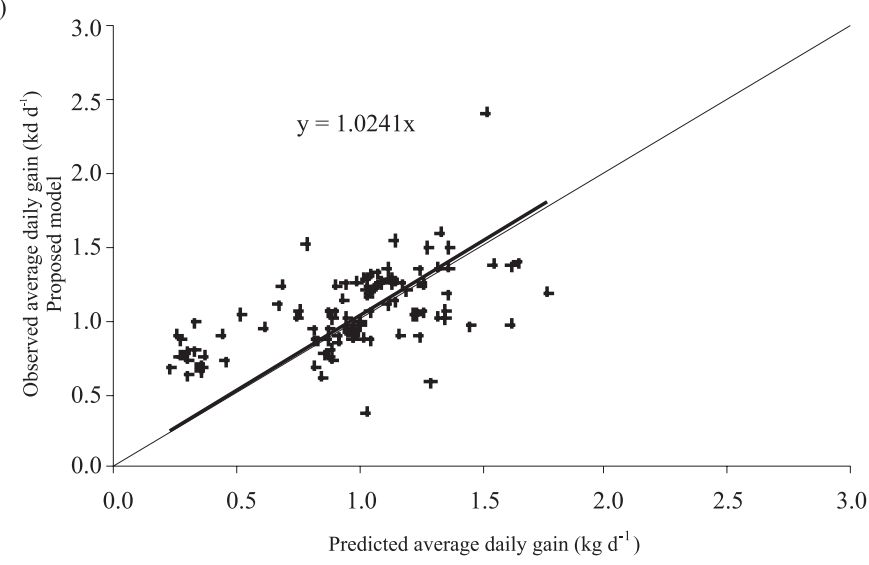

(c)

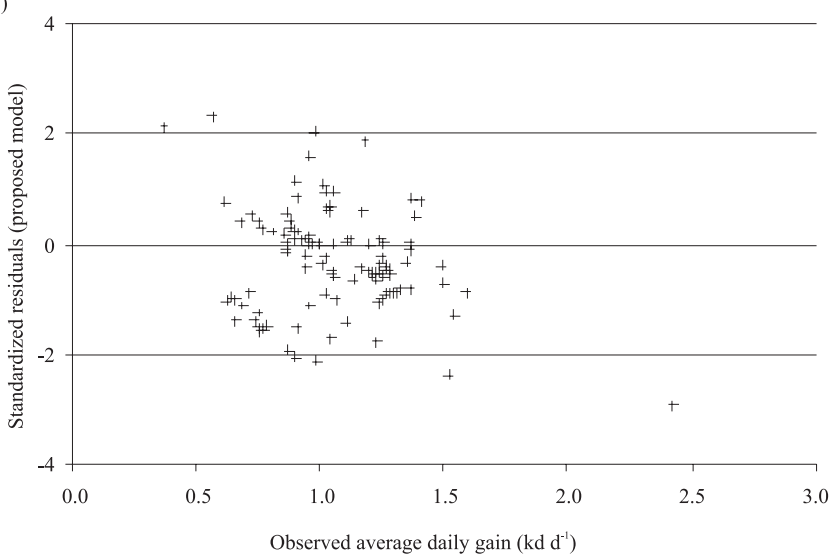

The proposed model was compared with the CNCPS (version 5.0) concerning the ability to predict body mass gain when observed dry matter intake and composition of the diet was used as input to the models (Figures 2, 3, 4 and Table 4). The predictions of the proposed model were closer to the observed values (Figure 2a, c), while CNCPS underestimated body mass gain (Figure 2b, d).

Kobayashi \& Salam (2000) presented a method for comparison of simulated and observed values using mean squared deviation (MSD) and its components: squared bias (SB), squared difference between standard deviations (SDSD), lack of correlation weighted by the standard deviation (LCS) and mean squared variation (MSV). According to these authors, the lower the MSD value the smaller the difference between predicted and observed values. Analysis of MSD results in the terms: SB, SDSD and LCS, whose sum is equal to MSD. SDSD's addition to LCS provides the MSV value. SB represents the difference between the means of observed and predicted values; SDSD measures the difference of magnitude of the (b)

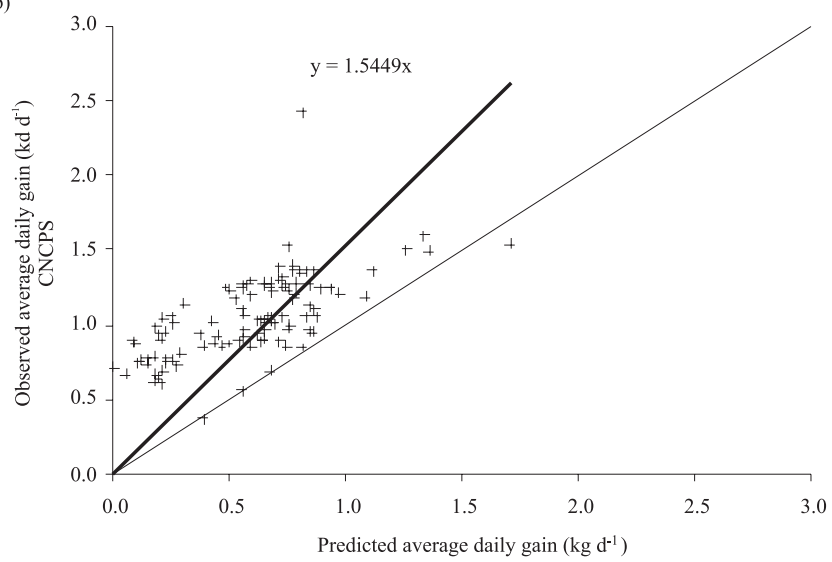

(d)

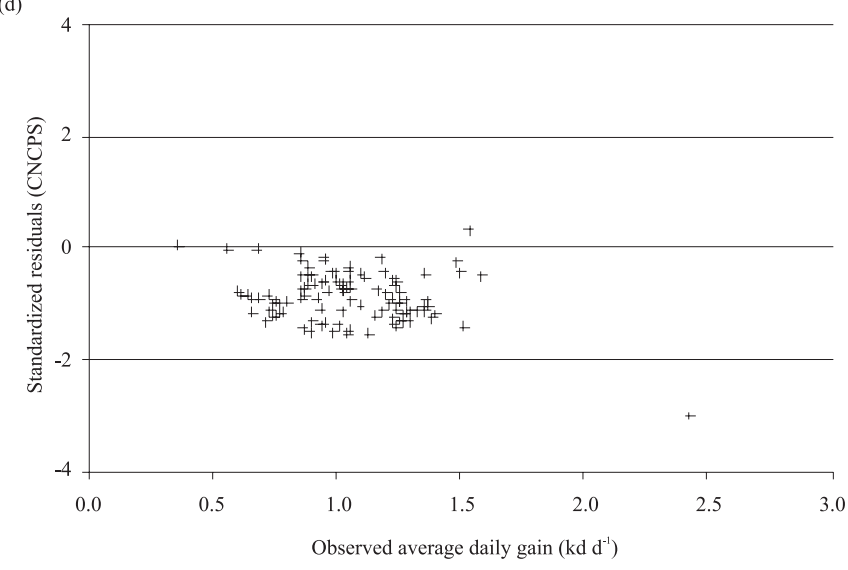

Figure 2 - Observed versus predicted body mass gain rate for the presented model (a) and the CNCPS (b); standardized residuals (predicted minus observed) of the body mass gain rate for the presented model (c) and the CNCPS (d), plotted against observed average daily gain. 
fluctuation between these values; LCS refers to the fluctuation pattern of these values and MSV quantifies the capacity of the model to simulate the variability of the measurements around the mean. Therefore, the smaller the value of each of those terms the better the predictive power of the model.

Mean squared deviation (MSD) and squared bias (SB) of the proposed model were smaller than that of the CNCPS, but SDSD, LCS and MSV were greater (Figure 3 and Table 4). However, the difference between SB of both models was so high that the best performance presented by CNCPS at the other three factors (SDSD, LCS and MSV) was not sufficient to counterbalance the difference in SB. Because of that, MSD, which is the sum of terms SB, SDSD and LCS, was smaller to the presented model. Those results indicate the superiority of the proposed model in relation to CNCPS to predict the body mass gain. But, CNCPS predicted the fluctuation of the observed values with more accuracy. This effect can be visualized when the standard residuals dispersion of the proposed model and of the CNCPS are compared in Figure 2c, d. In the referred figure, it is possible to notice that the proposed model standard residuals (Figure 2c) are more disperse than the CNCPS (Figure 2d), although almost all CNCPS standard residuals are below zero axis (Figure 2d).

The effect of fiber level in the diet upon energetic efficiency was tested using calculated values for these variables by both models (Figure 4a, b). The efficiency was calculated according to Van Soest (1994)'s proposition. Fiber level did not influence the energetic efficiency calculated with the equations of the proposed model

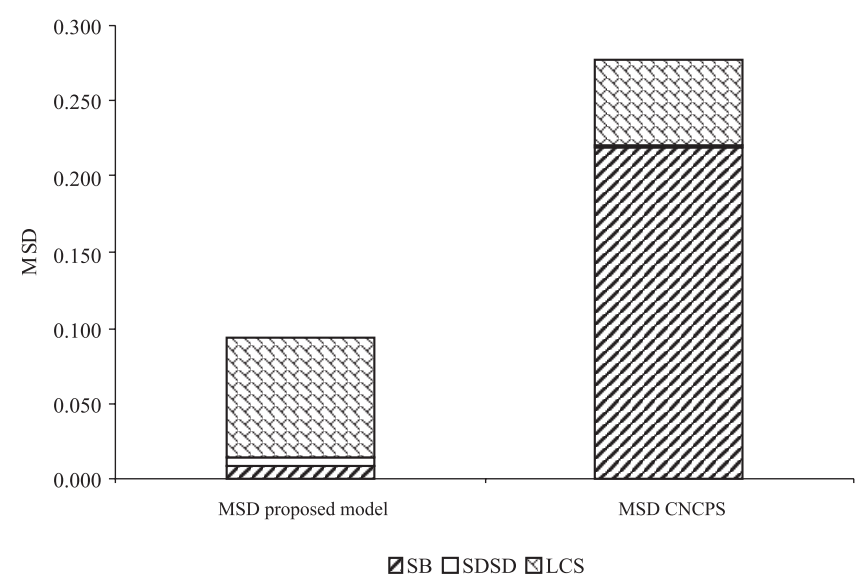

Figure 3 - Mean squared deviation (MSD) and its components: squared bias (SB), squared difference between standard deviations (SDSD), and lack of correlation weighted by standard deviation (LCS) in a comparison between the presented model and the CNCPS. $(\mathrm{r}=-0.14$ and $p-$ value $=0.14)$. However, the efficiency computed using CNCPS outputs was affected by diet concentration of fiber $(\mathrm{r}=-0.58$ and $p-$ value $<0.0001)$.

In Figure 4, the dispersions of standard residuals relative to observed and predicted body mass gain are a function of fiber level in the diet, obtained with the presented model (Figure 4c) and with CNCPS (Figure 4d). By visual analysis of these figures, we can see that the predictions of the presented model are closer to the values observed at higher levels of fiber in the diet (Figure 4c - standard residuals are closer to zero axis when the fiber level is above 0.40 ). The opposite occurred in relation to CNCPS: as the fiber level raised, the standard residuals got farther from the zero axis (Figure 4d).

The amplitude of fiber levels (18\% to $62 \%$ ) would be sufficient to cause some effect on efficiency, as it was seen with results related to CNCPS. However, the efficiency calculated from the outputs of the presented model was not affected by the fiber content of the diet (Figure 4a).

The superiority of the presented model in relation to CNCPS was, probably, a consequence of the proposed modifications to calculate: 1) degradation kinetic and passage of nutrients through rumen; 2) net energy and metabolizable protein requirements (based on proposed equations by Fontes (1995), and 3) gross efficiency of consumed metabolizable energy utilization (estimated from information generated at tropical climate conditions). The modifications related to fiber kinetic in rumen were based on concepts that were discussed in details by Allen \& Mertens (1988), Van Soest (1994) and Vieira et al. (2008a, b). The mechanistic characteristic of this part of the model may have improved the predictions in the situations where the fiber level in diet was higher. According to Van Soest (1994), mechanistic models have wider applicability than the empirical models, for being conceived from cause and effect relations and not only correlation between variables. To counterpart, equations utilized in the calculation of energy and protein requirements and the efficiency of metabolizable energy utilization are of empirical nature (both for the

Table 4 - Mean squared deviation and its components in a comparison between the present model and CNCPS

\begin{tabular}{lcc}
\hline Components & Proposed model & CNCPS \\
\hline $\begin{array}{l}\text { Squared bias (SB) } \\
\text { Squared difference between }\end{array}$ & 0.009 & 0.220 \\
standard deviations (SDSD) & 0.005 & 0.001 \\
$\begin{array}{l}\text { Lack of correlation weighted } \\
\text { by standard deviation (LCS) }\end{array}$ & 0.081 & 0.057 \\
$\begin{array}{l}\text { Mean squared variation (MSV) } \\
\text { Mean squared deviation (MSD) }\end{array}$ & 0.085 & 0.058 \\
\hline
\end{tabular}

CNPS = Cornell Net Carbohydrate and Protein System. 
proposed model and for CNCPS). According to Mertens (1987), empirical equations predict adequately, only when the situation to be predicted is similar to that in which the parameters were estimated, and in the presented model the estimates were obtained with information generated in climate and management conditions closer to the set of data used in the model evaluation, which can also justify its better predictive power.
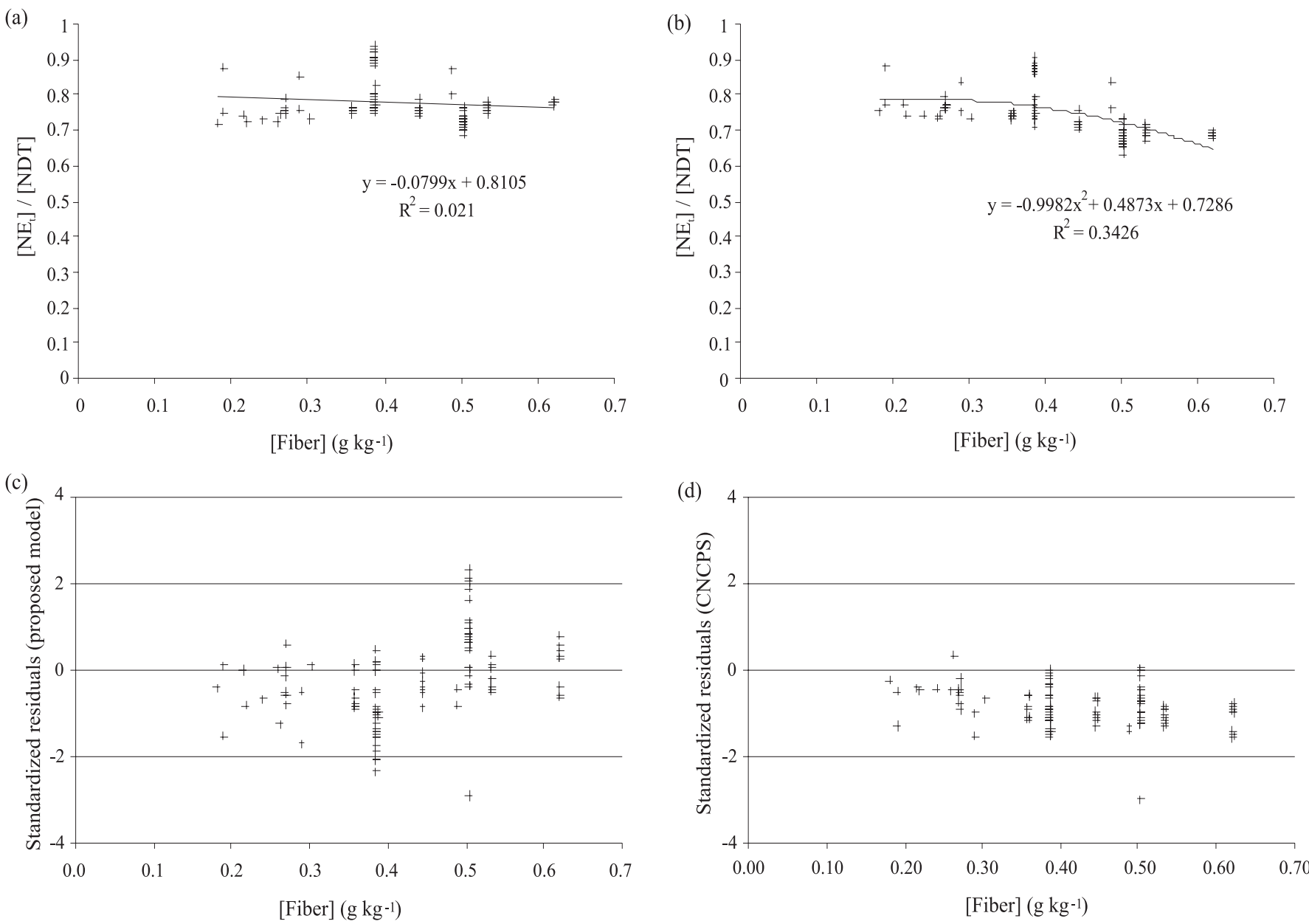

Figure 4 - Relationship between energetic efficiency, [NE $\mathrm{H}_{\mathrm{t}}$ / [NDT], and fiber content of the diet, [Fiber], calculated with the proposed model (a) and with CNCPS (b) and dispersion of standardized residuals (predicted minus observed) of body mass rate gain as a function of [Fiber] for the proposed model (c) and for CNCPS (d).

\section{Conclusions}

The differences of the proposed model in relation to CNCPS resulted in better predictions in tropical climate conditions, mainly when diets with higher levels of fiber were offered. The theoretical principles presented may be used to develop systems capable of evaluating rations offered to dairy cows and other domestic ruminant species such as goat and sheep. Therefore, the database of feed must be increased and more research must be done on the kinetic of degradation and passage of nutrients in rumen and the intermediary metabolism, in order to enhance the model's predictive power.

\section{Acknowledgements}

The authors would like to thank Katia Atoji Henrique for translating the paper into English.

\section{References}

AFERRI, G. Desempenho e características da carcaça de novilhos alimentados com dietas contendo diferentes fontes de gordura. 2003. 49f. Dissertação (Mestrado em Zootecnia) - Faculdade de Zootecnia e Engenharia de Alimentos/ Universidade de São Paulo, Pirassununga.

AGRAWAL, R.C.; HEADY, E.O. Operations research methods for agricultural decisions. Ames: The Iowa State University Press, 1972. 303p. 
ALLEN, M.S.; MERTENS, D.R. Evaluating constraints on fiber digestion by rumen microbes. Journal of Nutrition, v.118, p.261-270, 1988.

ALMEIDA, R. Consumo e eficiência alimentar de bovinos em crescimento. 2005. 181f. Tese (Doutorado em Agronomia) - Escola Superior de Agricultura Luiz de Queiroz/Universidade de São Paulo, Piracicaba.

ARRIGONI, M.B. Efeito da restrição alimentar sobre o desempenho, área e tipos de fibras musculares em bovinos jovens confinados. 1995. 73f. Tese (Doutorado em Zootecnia) - Faculdade de Ciências Agrárias e Veterinárias/ Universidade Estadual Paulista, Jaboticabal.

BACKES, A.A. Composição corporal e exigências de energia, proteína e macroelementos minerais, para bovinos mestiços leiteiros e zebu, castrados, em fase de recria e engorda, em confinamento. 2003. 97f. Tese (Doutorado em Zootecnia) - Universidade Federal de Viçosa, Viçosa, MG.

BARBOSA, C.A.N. Rações com três níveis de energia para novilhos mestiços em confinamento. 1978. 33f. Dissertação (Mestrado em Zootecnia) - Universidade Federal de Viçosa, Viçosa, MG.

BLAXTER, K.L. The energy metabolism of ruminants. 3.ed. London: Hutchinson \& Co., 1969. 332p.

BRODERICK, G.A. Quantifying forage protein quality. In: FAHEY JR., G.C.; COLLINS, M.; MERTENS, D.R.; MOSER, L.E. (Eds). Forage quality, evaluation and utilization. Madison: American Society of Agronomy, Crop Science Society of America, 1994. p.200-228.

BULLE, M.L.M. Desempenho, composição corporal e exigências líquidas de energia e proteína de tourinhos de dois tipos genéticos alimentados com dietas de alto teor de concentrado. 2000. 50f. Dissertação (Mestrado em Agronomia) - Escola Superior de Agricultura Luiz de Queiroz, Universidade de São Paulo, Piracicaba.

CHIZZOTTI, F.H.; PEREIRA, O.G.; VALADARES FILHO, S.C. et al. Consumo, digestibilidade total e desempenho de novilhos nelore recebendo dietas contendo diferentes proporções de silagens de Brachiaria brizantha cv. Marandu e de sorgo. Revista Brasileira de Zootecnia, v.34, p.2427-2436, 2005 (supl.).

DRAPER, N.R.; SMITH, H. Applied regression analysis. New York: John Wiley \& Sons, 1966. 407p.

ESTRADA, L.H.C. Composição corporal e exigências de proteína, energia e macroelementos minerais (Ca, $P$, $\mathrm{Mg}, \mathrm{Na}, \mathrm{K})$, características da carcaça e desempenho do Nelore e mestiços em confinamento. 1996. 128f. Tese (Doutorado em Zootecnia) - Universidade Federal de Viçosa, Viçosa, MG.

FATURI, C. Fontes de carboidratos solúveis e níveis de fibra em detergente neutro em dietas para terminação de novilhos em confinamento. 2005. 73f. Tese (Doutorado em Zootecnia) - Faculdade de Ciências Agrárias e Veterinárias, Universidade Estadual Paulista, Jaboticabal.

FERNANDES, J.J.R. Farelo de soja em substituição à uréia em dietas para bovinos de corte em crescimento e terminação. 2004. 74f. Tese (Doutorado em Agronomia) Escola Superior de Agricultura Luiz de Queiroz/Universidade de São Paulo, Piracicaba.

FERNANDES, J.F.; PAULINO, M.F.; MARTINS, R.G.R. et al. Ganho de peso, conversão alimentar, ingestão diária de nutrientes e digestibilidade de garrotes não-castrados de três grupos genéticos em recria e terminação. Revista Brasileira de Zootecnia, v.33, n.3, p.2403-2411, 2004 (supl.).

FONTES, A.A. Níveis de proteína e quantidades de concentrado com silagem no desempenho de novilhos Holandês-Zebu em confinamento. 1993. 91f. Dissertação (Mestrado em Zootecnia) - Escola Superior de Agronomia de Lavras, Lavras.

FONTES, C.A.A. Composição corporal, exigências líquidas de nutrientes para ganho de peso e desempenho produtivo de animais zebuínos e mestiços europeu-zebu. Resultados experimentais. In: SIMPÓSIO INTERNACIONAL SOBRE EXIGÊNCIAS
NUTRICIONAIS DE RUMINANTES, 1995, Viçosa, MG. Anais... Viçosa: Universidade Federal de Viçosa, 1995. p.419.

FOX, D.G.; SNIFFEN, C.J.; O’CONNOR, J.D. et al. A net carbohydrate and protein system for evaluating cattle diets: III. Cattle requirements and diet adequacy. Journal of Animal Science, v.70, n.12, p.3578-3596, 1992.

FOX, D.G.; TYLUTKI, T.P.; PELL, A.N. et al. The net carbohydrate and protein system for evaluating herd nutrition and nutrient excretion: Model documentation. Ithaca: Cornell University, 1999. 75p.

FOX, D.G.; TEDESCHI, L.O.; TYLUTKI, T.P. et al. The cornell net carbohydrate and protein system model for evaluating herd nutrition and nutrient excretion. Animal Feed Science and Technology, v.112, p.29-78, 2004

GALVÃO, J.G.C. Estudo da eficiência nutritiva, características e composição física da carcaça de bovinos de três grupos raciais, abatidos em três estágios de maturidade. 1991. 82f. Dissertação (Mestrado em Zootecnia) - Universidade Federal de Viçosa, Viçosa, MG.

GESUALDI JÚNIOR, A. Níveis de concentrado na dieta de novilhos $F 1$ Limousin $x$ Nelore em confinamento: desempenho produtivo e características de carcaça. 1999 62f. Dissertação (Mestrado em Zootecnia) - Universidade Federal de Viçosa, Viçosa, MG

HALL, M.B. Challenges with nonfiber carbohydrates methods. Journal of Animal Science, v.81, n.12, p.3226-3232, 2003.

HENRIQUE, W. Utilização de polpa cítrica peletizada para tourinhos em terminação. 2002. 82f. Tese (Doutorado em Zootecnia) - Faculdade de Ciências Agrárias e Veterinárias/ Universidade Estadual Paulista, Jaboticabal.

HENRIQUE, D.S.; VEIRA, R.A.M.; MALAFAIA, P.A.M. et al. Estimation of metabolizable energy utilization for maintenance and growth by cattle in tropical conditions. Revista Brasileira de Zootecnia, v.34, n.3, p.1006-1016, 2005

HENRIQUE, D.S. Desenvolvimento e avaliação de um modelo matemático para predição do valor nutricional de rações para bovinos sujeito às restrições da massa de fibra no rúmen. 2007. 108f. Tese (Doutorado em Zootecnia) Universidade Federal de Viçosa, Viçosa, MG.

JOHNSON, D.E.; FERREL, C.L.; JENKINS, T.G. The history of energetic efficiency research: Where have we been and where are we going? Journal of Animal Science, v.81 (E. Suppl. 1): E27-E38, 2003.

KOBAYASHI, K.; SALAM, M. Comparing simulated and measured values using mean squared deviation and its components. Agronomy Journal, v.92, p.345-352, 2000.

LANGUIDEY, P.H. Melaço de cana e ou mandioca dessecada em rações contendo uréia para novilho de corte. 1975. 50f. Dissertação (Mestrado em Zootecnia) - Universidade Federal de Minas Gerais, Belo Horizonte.

LEÃO, R.V. Efeitos da substituição do grão de milho pelo de milheto (Pennisetum glaucum (L.) Br.) na digestibilidade dos nutrientes e no desempenho de bovinos confinados. 2002. 29f. Dissertação (Mestrado em Zootecnia) - Faculdade de Engenharia, Universidade Estadual Paulista, Ilha Solteira.

MAGALHÃES, K.A. Níveis de uréia ou casca de algodão na alimentação de novilhos de origem leiteira em confinamento. 2003. 90f. Dissertação (Mestrado em Zootecnia) - Universidade Federal de Viçosa, Viçosa, MG.

MARGON, A.L. Requerimentos de macrominerais (Ca, P, Mg, Na e k) para engorda de novilhos zebu. 1981. 74f. Dissertação (Mestrado em Zootecnia) - Universidade Federal de Viçosa, Viçosa, MG.

MENDES, A.R. Fontes energéticas associadas ao farelo de girassol em dietas para bovinos em confinamento. 2003. 103f. Tese (Doutorado em Zootecnia) - Faculdade de Ciências Agrárias e Veterinárias, Universidade Estadual Paulista, Jaboticabal.

MERTENS, D.R. Predicting intake and digestibility using mathematical models of ruminal function. Journal of Animal Science, v.64, n.6, p.1548-1558, 1987. 
MIRANDA, E.N. Composição corporal e exigências nutricionais de macroelementos minerais ( $\mathrm{Ca}, \mathrm{P}, \mathrm{Mg}$, Na e $\mathrm{K}$ ) de bovinos nelore e caracu selecionados para peso aos 378 dias de idade. 2005. 71f. Dissertação (Mestrado em Zootecnia) - Universidade Federal de Viçosa, Viçosa, MG.

MONTGOMERY, D.C. Design and analysis of experiments, 6.ed. Nova Iorque: John Wiley \& Sons Co., 2005. 643p.

NATIONAL RESEARCH COUNCIL - NRC. Nutrient requirements of beef cattle. 7.ed. Washington: National Academy Press, 1996. 242p.

NATIONAL RESEARCH COUNCIL - NRC. Nutrient requirements of dairy cattle. 7.ed. Washington: National Academy Press, 2001. 381p.

OBEID, J.A. Desempenho e parâmetros nutricionais de bovinos de corte alimentados com dietas contendo diferentes níveis de proteína bruta. 2005. 60f. Tese (Doutorado em Zootecnia) - Universidade Federal de Viçosa, Viçosa, MG.

OLIVEIRA, M.G. Desempenho de bovinos confinados suplementados com diferentes ionóforos. 2004. 55p. Dissertação (Mestrado em Zootecnia) - Faculdade de Zootecnia e Engenharia de Alimentos/Universidade de São Paulo, Pirassununga.

PACOLA, L.J. Alimentação suplementar de bezerros zebus: influência sobre a idade dos machos ao abate e das fêmeas à primeira cobrição. 1977. 83f. Dissertação (Mestrado em Zootecnia) - Universidade Federal de Minas Gerais, Belo Horizonte.

PEREIRA, A.S.C. Qualidade da carne de bovinos Nelore (Bos taurus indicus) suplementados com vitamina E. 2002. 83f. Dissertação (Mestrado em Zootecnia) - Faculdade de Zootecnia e Engenharia de Alimentos/Universidade de São Paulo, Pirassununga.

PEREIRA, D.H.; PEREIRA, O.G.; VALADARES FILHO, S.C. et al. Consumo, digestibilidade dos nutrientes e desempenho de bovinos de corte recebendo silagem de sorgo (Sorghum bicolor (L.) Moench) e diferentes proporções de concentrado. Revista Brasileira de Zootecnia, v.35, p.282-291, 2006.

PUTRINO, S.M. Exigências de proteína e energia líquidas para o ganho de peso de tourinhos das raças Nelore e Brangus alimentados com dietas com diferentes proporções de concentrado. 2002. 75f. Dissertação (Mestrado em Zootecnia) - Faculdade de Zootecnia e Engenharia de Alimentos/Universidade de São Paulo, Pirassununga.

RESENDE, F.D. Avaliação de diferentes proporções de volumoso:concentrado sobre a ingestão, digestibilidade, ganho de peso e conversão alimentar de bovinos mestiços confinados. 1999. 78f. Tese (Doutorado em Zootecnia) Universidade Federal de Viçosa, Viçosa, MG.

RODRIGUES, M.T.; VIEIRA, R.A.M. Metodologias aplicadas ao fracionamento de alimentos. In: BERCHIELLI, T.T.; PIRES, A.V.; OLIVEIRA, S.G. (Eds.) Nutrição de ruminantes. Jaboticabal: FUNEP, 2006. 583p.

RUSSELL, J.B.; O'CONNOR, J.D.; FOX, D.G. et al. A net carbohydrate and protein system for evaluating cattle diets: I. Ruminal Fermentation. Journal of Animal Science, v.70, n.12, p.3551-3561, 1992.

SILVA, B.C.; PEREIRA, O.G.; PEREIRA, D.H. et al. Consumo e digestibilidade aparente total dos nutrientes e ganho de peso de bovinos de corte alimentados com silagem de Brachiaria brizantha e concentrado em diferentes proporções. Revista Brasileira de Zootecnia, v.34, n.3, p.1060-1069, 2005.

SNIFFEN, C.J.; O'CONNOR, J.D.; VAN SOEST, P.J. et al. A net carbohydrate and protein system for evaluating cattle diets: II. Carbohydrate and protein availability. Journal of Animal Science, v.70, n.12, p.3562-3577, 1992.

TEDESCHI, L.O.; FOX, D.G.; RUSSELL, J.B. Accounting for the effects of a ruminal nitrogen deficiency within the structure of the Cornell net carbohydrate and protein system. Journal of Animal Science, v.78, p.1648-1658, 2000.

VALADARES FILHO, S.C.; MAGALHÃES, K.A.; ROCHA JUNIOR, V.R. et al. Tabelas brasileiras de composição de alimentos para bovinos. 2.ed. Viçosa, MG: Universidade Federal de Viçosa, 2006. 329p.

VAN SOEST, P.J. Development of a comprehensive system o feed analyses and its application to forages. Journal of Animal Science, v.26, n.1, p.119-128, 1967.

VAN SOEST, P.J.; ROBERTSON, J.B.; LEWIS, B.A. Methods for dietary fiber, neutral detergent fiber, and nonstarch polyssacharides in relation to animal nutrition. Journal of Dairy Science, v.74, n.11, p.3583-3597, 1991.

VAN SOEST, P.J. Nutritional ecology of the ruminant. 2.ed. Ithaca: Cornell University Press, 1994. 476p.

VIEIRA, R.A.M.; TEDESCHI, L.O.; CANNAS, A. A generalized compartmental model to estimate the fibre mass in the ruminoreticulum: 1. Estimating parameters of digestion. Journal of Theoretical Biology, v.255, p.345-356, 2008a.

VIEIRA, R.A.M.; TEDESCHI, L.O.; CANNAS, A. A generalized compartmental model to estimate the fibre mass in the ruminoreticulum: 2. Integrating digestion and passage. Journal of Theoretical Biology, v.255, p.357-368, 2008b. 